\title{
Changing the opinions, beliefs and attitudes of the Efiks, Quas and Efuts of Calabar Municipality towards the practice of female circumcision
}

Oyira Emilia James *1, Emon Umoe Duke ${ }^{1}$, Essien $\mathrm{NC}^{1}$, Affiong Ekpenyong Onoyom², Egbai ME ${ }^{3}$, Mbum Patrick Awok $^{4}$

${ }^{1}$ Department of nursing science, University of Calabar, Calabar, Nigeria

${ }^{2}$ School of health technology, Calabar, Cross River States, Nigeria

${ }^{3}$ Department of administration and planning faculty of education, University of Calabar, Calabar, Nigeria

${ }^{4}$ Department of marketing faculty of management sciences, University of Calabar, Nigeria

Received: December 14, 2014

Accepted: March 29, 2015

Online Published: April 28, 2015

DOI: $10.5430 /$ jha.v4n3p61

URL: http://dx.doi.org/10.5430/jha.v4n3p61

\begin{abstract}
Objective: To determine the opinion of the Efiks, Quas and Efuts of old Calabar district towards the practice of female circumcision. To examine the beliefs of the Efiks, Quas and Efuts of Calabar towards the practice of female circumcision. To determine the attitude of the Efiks, Quas and Efuts of Calabar towards the practice of female circumcision.

Methods: In order to successfully carry out the study, three research questions and hypothesis were formulated. Literatures were reviewed based on the research variables. The research instrument used for data collection was questionnaire which was administered on three hundred and six (306) respondents who served as the sample for the study. Their responses were analyzed using frequencies, and percentages. Results showed that more than 50\% are not in support of the practice and in fact more than $64 \%$ will not want their daughters circumcised.

Results: It is observed that majority of educated, well informed and enlightened individuals who are aware of the harmful effects of the female circumcision abhors it. To this extent, proper education, and enlightenment, should be encouraged. Religions and cosmopolitan nature of the city are key to influencing the opinions, beliefs and attitude of the people living there. And finally, majority of the people think that the practice of female circumcision is decreasing in the city. Based on these findings information should continue to be disseminated using mass media and local languages for complete eradication and permanent attitudinal change.

Conclusions: This work highlight the influence of public education and increase awareness from both the rural and urban communities so rooted to their cultures of female circumcision in old Calabar district as bad practice and unacceptable tradition in the $21^{\text {st }}$ century world of today.
\end{abstract}

Key Words: Changing, Opinion, Beliefs, Attitude, Female circumcision

\section{INTRODUCTION}

\subsection{Background to the study}

In contemporary society, the practice of female circumcision is commonest in Africa and about 20 million women are cur- rently affected in Africa. ${ }^{[1]}$ It is also estimated that at least two million girls annually are at risk of genital mutilation, approximately 600 per day and an estimated total of 130 million girls and women in the world are mutilated. ${ }^{[2]}$ Nigeria.

*Correspondence: Oyira Emilia James; Email: emioyira@yahoo.com; Address: Department of nursing science, University of Calabar, Calabar, 
In Nigeria and Calabar in particular, female circumcision is widely practiced among many groups cross culturally. The Efik, Quas and Efuts in Calabar are noted groups with classical sense of preserving, observing and performing certain traditional rites and customs among which is the practice of female circumcision. Female circumcision is mostly carried out while the girls are in the fattening rooms in preparation for marriage. At times, it is performed very early in the life of the girl, usually between the ages of seven and eight just before the onset of menstruation. ${ }^{[3]}$ It is performed by traditional midwives or traditional birth attendants. ${ }^{[3]} \mathrm{Fe}$ male circumcision refers primarily to the removal of the clitoral foreskin and secondarily to a variety of other genital operations. $^{[4]}$

Talbot ${ }^{[5]}$ defines female circumcision as excision which usually consists of Clitoridectomy but among some people in Southern Nigeria, it involves parts of the labia majora and minora being cut off and the entrance of the vagina at times enlarge. Differently put, female circumcision involves partial or complete excision of the external female genitalia.

There are many forms or types of female circumcision as described by several authorities. The pharoanic type of female circumcision is the one associated with negative consequences and severe complications. ${ }^{[1]}$ This is uncommon among the three major tribes of Calabar.

Clitoridectomy-removal of either a part or the whole clitoris is practiced among Calabar groups of people. Female circumcision carries with it serious health hazards. Apart from the traumatic pains associated with the cutting of the tissue, other health complications including shock, severe bleeding sometimes leading to death and infections such as Tetanus - if the operation is performed under unhygienic condition. Some women experience uncontrollable tear during delivery because of scar formation. Yet, others may experience dyspareunia or pain during intercourse, dysmenorrheal, delayed menarche, colloids and desmoids cysts. ${ }^{[6]}$

Inspite of the health hazards female circumcision is a common practice among many people in Nigeria and Africa. In some communities in Calabar Municipal Council, the practice of female circumcision is a long standing custom. In fact, it origin is in antiquity. However, due to its adverse effects on individual's health, it has been widely condemned as a custom in many quarters. In recent years, there has been increasing opposition against this practice because of it severe side effects immediate and long term which at times lead to serious health complication. However, inspite of the health hazards involve in the practice and public enlightenment by government on the negative effect of female circumcision, it is still practiced among the people of Calabar urban. It is on this note that this research is being conducted to investigate the beliefs, opinions and attitudes vis-à-vis their implications on the practice?

\subsection{Importance}

The significance of this work is that the influence of public education and enlightenment on the beliefs and practices of female circumcision in old Calabar in particular and urban areas in Nigeria in general. The study adds to increasing literature volume on aspects of female circumcision and is expected to generate academic debates and discussions which might go a long way toward increasing understanding of the danger involved in female circumcision and ways to curb or eliminate the practice.

\subsection{Goals}

Our goal is to cause a change in the opinions, beliefs and attitudes of the Efiks, Quas, and Efuts in the old Calabar district toward outdated fashion and fads of female circumcision or what is referred to as genital mutilation.

\section{REVIEW OF RELATED LITERATURE}

\subsection{Certain opinion's associated with female circumci- sion}

Authors agreed that female circumcision is an ancient custom and that the practice of various forms of it remains unknown. ${ }^{[7]}$ Inspite of the existing of conflicting theories trying to explain it, ${ }^{[1,2]}$ female circumcision indeed could only be traced back to antiquity conceivably to the very beginning of mankind. ${ }^{[8]}$ It is viewed that at some early point in human history circumcision replaced human sacrifices as a way of placating hostile forces and spirits. For instance, origin claims that the Jewish practice was a safeguard against some angels hostile to that race. ${ }^{[5]}$ Yet, there is a strong speculation that the practice resulted from early man's desire to gain ascendancy over the mystery of female sexual function. The opinion is that by excision of the clitoris sexual function in women could be curbed and women were changed from common to private property - i.e. the property of their husband alone. To this Giogis takes the origin of female circumcision to the development of patriarchal family system which dictated that a woman could only have one husband although a man could have several spouses. Strong patriarchal system restricted women's sexuality for the purpose of preserving male's linage. Talbot ${ }^{[5]}$ maintain that the system female circumcision was performed on virgins, widows, divorcees and on women whose husband were away on journeys in ancient Egypt girls could not marry, inherit property or enter places of worship unless they were circumcised. However, in ancient Egypt reports show that, the practice was restricted to rulers, priest and their families. ${ }^{[1]}$ 
Studies have revealed that there is a direct relationship between level of education and the practice of traditional management of female circumcision. In this case, the higher the level of education, the less likely she is to practice traditional practice of female circumcision. For instance, analysis revealed that the $31(24.8 \%)$ illiterate women who participated in the study, $94 \%$ of them agreed that traditional practice is a compulsory rite while only $35(45 \%)$ of the $70(56 \%)$ of the educated NCE (OND) subject agreed that is compulsory.

Similarly, $65 \%$ of the illiterate as compared to zero percent of the educated, the tertiary wish that the practice be discounted. These findings disagreed with that of Ogunmodede, ${ }^{[9]}$ who observed in her study that young educated mothers in Africa and Sudan in particular are pushed into accepting the traditional practice of circumcision.

\subsection{General beliefs of Africans on female circumcision}

Another explanation for the practice of female circumcision was the pharoanic belief in the God of bisexuality. The ancient Egyptians believed that a certain god is bisexual. Consequently, every person is believed to be endowed with masculine and feminine "soul" - the genital organs revealed the physiological characteristics of the "soul" of men. Thus, the female "soul" of the men, so it is maintained, is located in the prepuce, whereas the masculine "soul" of the woman is situated in the clitoris. This implies that for a boy to grow up and be finally accepted into masculine society he has to shed feminine property. This is done by the removal of the prepuce, the feminine portion of this original sexual state. Similarly for a young girl accepted into the feminine society she has to be delivered from her masculine property by having her clitoris and labia cut away only thus circumcised can the boy and the girl is fully a man and a woman respectively and thus capable of sexual life. ${ }^{[1]}$

Whatever the origin of, and explanation for the practice of female circumcision record has indicated that the custom is an ancient as the days of Pharaohs in Egypt (Exodus 1: 15-19). Today, female circumcision is a worldwide practice. In W.H.O claims that "there is no single continent which has been exempted from this ancient custom". Toubia ${ }^{[2]}$ gives a global estimate of at least two million girls annually are at risk of genital mutilation approximately 6,000 per day and estimated total 130 million girls and women are mutilated. However, authors are agreed that at present the practice of female circumcision is most prevalent in Africa. ${ }^{[1,4]}$ "At present, the practice of female circumcision is commonest in Africa and an estimated of 20 million women currently affected in African is considered conservative". [1] However, according to a $1981 \mathrm{UN}$ report, "the practice is declining owing to opposition by African women". [4]

Published by Sciedu Press

\subsection{Attitude of women towards female circumcision}

Girls are now being circumcised at an early age in most African societies for some reasons. ${ }^{[8]}$ A younger girl is more easily controlled and being unaware of what would happen to her put up no resistance. ${ }^{[10]}$ Performing the operation on a younger girl is regarded as being less psychologically traumatic. Some of the children cannot remember what it felt like as the genitalia had not fully developed at the time of circumcision. Also, it is known that there is likely to be less damage to the genital area as a small child can easily be forcibly held down to minimized her movement.

The performance of the female circumcision is always done by women. ${ }^{[5]}$ The traditional practices vary among different African ethnic groups. Most of the operation is done by traditional midwives, roving "gypsies" and fortune "tellers". In Northern Nigeria among the Hausa, barbers perform the surgery. ${ }^{[8]}$ Such instruments as razor blades, scissors, kitchen knives, and less frequently pieces of glass are used. However, in urban areas, particularly among the elite, doctors, or trained nurses/midwives perform circumcision in a clinic-like environment setting under sterile conditions, using anesthesia. However, Ismail reports that when anesthesia is used, more tissue is opt to be cut away, as the child tends to struggled less. There is a serious controversy surrounding the continued practice of female circumcision even at the close of the $20^{t h}$ century. Indeed, the arguments for and against the practice are several and "vary from one country to country and from culture to culture". ${ }^{[8]}$

\subsection{Social customs associated with female circumcision}

Circumcision for both boys and girls is a highly valued custom and indeed is one of the main initiation rites in many parts of Africa. An individual is recognized to be an adult as the cutting of the flesh is a symbol of getting rid of the period of adulthood. ${ }^{[6]}$ Female circumcision like that of the males was initially an initiation rite in Africa making a child's passage from puberty to adulthood thus becoming a full member of the tribe. ${ }^{[7,11,12]}$ Without circumcision an individual is not given full responsibilities at home and in the community and may not enjoy certain privileges ${ }^{[7]}$.

Female circumcision is thus simply a custom and where it is practiced everybody must bow to custom or face the penalty for defiance total ostracism. ${ }^{[8]}$ Similar explains further that without circumcision a person is still considered to be a child, no matter how old she might be, and it is considered shameful to be isolated from one's age mate through lack of this experience. ${ }^{[6]}$ Female circumcision among the Kikuyu of Kenya as being part of the tribal psychology. ${ }^{[13]}$ Describing further he observes that female circumcision "operation is 
regarded" (among the Kikuyu) as the very essence of institution of which has enormous educational social, moral and religious implications. In this vein, circumcision as part of an initiation into womanhood and thus "a gateway to marriage, as many gets married soon after it under normal conditions". ${ }^{[7]}$ During the initiation rite the girl is usually put in fattening room for a period of seclusion and is taught many things concerning life of her people, its history, traditions, beliefs, and above all how to raise a family. In some tribes nobody is allowed to get married before getting through the initiation. $^{[7]}$ In some societies in West and East Africa a woman is considered neither clean nor pure if she has not been excised of clitoris. ${ }^{[1]}$ Similarly, Nguwu considered the Ogbaru of Nigeria, tradition forbids uncircumcised woman to deliver babies thus they are circumcised during their first pregnancy often complicating birth with severe hemorrhage and genital infection among the Bambara an uncircumcised woman is ridiculously regarded as carrying about "germ" of clitoris and so very dirty. The clitoris is considered unsightly and unpleasant to touch. ${ }^{[12,14]}$ It is therefore considered a sign of maturity when a woman's "ugly genitalia" have been removed. ${ }^{[8]}$

It is also the belief of the Bambara that the clitoris is poisonous and will kill a man if it comes in contact with his penis during intercourse. ${ }^{[8]}$ Among the Yoruba in Nigeria, the traditional reason given for the practice of female circumcision is that as the clitoris touches the head of a new born child, the later would die. ${ }^{[2]} \mathrm{Mbiti}^{[7]}$ confirms this observation among the Yoruba, claiming that they believe that clitoris is an aggressive organ which should not touch the head of the body during delivery as the baby will be killed or develop hydrocephalic head. Also, he observed the Yoruba practice excisions as a form of contraception as they believe that sperm may enter into a nursing mother's milk and cause excision enables the nursing mother to abstain from sex, so that she avoid having her contaminated. Many societies believes that the clitoris represents a "malefic power" and it removal ensures feminity and fecundity. ${ }^{[1]}$ The Mandingo believes that circumcision enhances fertility. ${ }^{[8]}$ Thus, belief is also common among other Africans such as the Tangoniana Cote D'Ivoire who claims that an uncircumcised female is incapable of bearing children. ${ }^{[2]}$ Another belief is that excision enlarges vaginal orifice and thus make child bearing easier, ${ }^{[15]}$ thus according to Mbiti ${ }^{[7]}$ "circumcision and Clitoridectomy are practiced, they symbolically represent the flow of life through the shedding of blood from the organs of reproduction. Thus is a proof religious set by means of which the young people accept that they have become bearers of children, and their community's approval to that step".

\subsection{Beliefs on health benefits of female circumcision}

It is also belief in some societies that circumcision maintains good health in a woman. ${ }^{[16]}$ According to Mbiti, ${ }^{[7]}$ evidence is often quoted of girls, who are always sick, but after circumcision become healthy and hearty. Moreover, the circumcision is often credited with healing power. It is claimed to have cured women suffering from melancholia, hysteria, insanity, epilepsy, kleptomania and proneneness to truancy. ${ }^{[16]}$

Female circumcision is believed to enhance sexual pleasure of the man. "The operation" according to "is thought to enhance male sexual pleasure, and some women in the United State today undergo a gynecological operation with the purpose of tightening the genital orifice to improve theirs and their partner's sexual pleasures". In the same vein, female circumcision is occasionally employed in the United State of America in attempt to enhance orgasmic response. ${ }^{[4]} \mathrm{How}-$ ever according to the source, the successes of the operation of the procedure have not been scientifically evaluated.

There is a strong belief among many groups in Nigeria, Africa and elsewhere in the world that female circumcision reduces female libido and thus prevents promiscuity. According to the belief the operation is seen as "a belt of chastity in that it decreases the sexual desire of girl". The manifest function of pharoanic circumcision is to regulate female sexuality in order to safeguard virginity, thus protecting the hour of a woman and her husband's patrilneages. ${ }^{[1]}$ Similarly, female circumcision is performed in order to protect the family honour as it tends to decrease their sexual urge before marriage. ${ }^{[9]}$ This prevents the girl from being wayward and bringing shame on the families. Africans also maintain the belief that by removing parts of the sexual organs and thus preventing her attaining pleasure she will not be tempted in extramarital affair. ${ }^{[12]}$

\section{METHODS}

\subsection{Study design}

This research study is exploratory in nature aimed at describing, explaining, and changing the opinions, beliefs and attitude of Calabar Municipal people towards the practice of female circumcision. This research was supported with related literature and findings revealed the complications and the negative consequences following the practice of female circumcision and the people of Calabar Municipality might have a change of opinion, beliefs and attitude towards the practice of female circumcision preventing the women accepting the practice. Thus, primary and secondary data were used. 


\section{Outcomes}

The study area of the research is the city of Calabar, the capital of Cross River State of Nigeria. The ancient city of Calabar lies at latitude $4^{\circ} 7^{\prime} \mathrm{N}$ and longitude $8^{\circ} 20^{\prime} \mathrm{E}$ and is situated on the left bank of Cross River. It is therefore found at the extreme end of South Eastern Nigeria. Calabar is the capital of Cross River State and is accessible by road, air and water. Calabar urban is made up of three ethnic groups the Efiks, Quas and Efuts. These migrated at various times in history from different places to occupy their present locations.

\subsection{Study ethics}

An introductory letter was given to the researchers from the department of Nursing Science, University of Calabar, which was used to obtain permission from the authority of the chiefs in Calabar Municipality. Informed consents were obtained from the respondents while their opinions were respected during the study.

Calabar was one of the earliest towns to have contact with the Europeans on their arrival in the West Coast of Africa. It is worthy of note that Calabar is a Metropolitan city but cosmopolitan in nature with a population of about $371,967 .{ }^{[17]}$

\subsection{Study setting target population}

The target population for this study comprises women of child bearing age between 15 and 49 years of age in the municipality. The men were not part of the study but, for further studies their opinion will be viewed.

\subsection{Sampling techniques}

Calabar Municipality consists of 19 wards and is (imperceptibly) divided into three core geographical areas. Calabar Municipality has a population of 320,862 with a yearly increase of $3 \%$ project to $371,967 .{ }^{[17]}$ Because of limited time and resources the study was restricted to two wards in each of the three main/core areas Efik, Qua, and Efut. Since Calabar Municipality is divided into three main core geographical areas. Stratified random sampling technique was adopted in sampling of respondents from the two wards in each of the core areas. Consequently, a total of six wards were randomly selected for the study.

\subsection{Study instrument}

The main instrument used for data collection was structured questionnaire. Information was also gathered through personnel interviews and discussions. The format for the questionnaire was carefully drawn to cover all the areas of the topic under study. The questionnaires contained items of information as regards the opinions, beliefs, and attitudes of people of Calabar Municipality towards female circumcision. The questionnaires consist mostly of closed ended questions for easy classification and quantifications.

The main instrument format, the questionnaire was preferred because of time constraint, it comparative cheapness as well as the fast and efficient method of obtaining large amount of quantifiable data.

\subsubsection{Validation of instrument}

In order to validate the instrument opinion, beliefs and attitude of the Efiks, Quas and Efuts of Calabar Municipality towards the practice of female circumcision questionnaire draft copies were presented to experts in the measurement and evaluation to vouch safe for face validity which is the extent to which a research instrument appears to deal with relevant content in the desired sub-test area, face validity of an instrument is obtained through a superficial examination of content of the research instrument and the establishment of the fact that the content is measuring what it want to measure.

\subsubsection{Reliability of the instrument}

In order to determine the reliability of the instrument a pilot study was conducted with a group of 15 women who are not included in the study. The researcher employed two staff to help in the exercise.

The 15 women who took part in the study were captured twice during visitation in area of study. During the second data collection exercise the employ staff for the trial test were made to repeat visitation to the areas they covered in the first test to ensure that the women who completed the questionnaire in the first were spotted and made to complete the same type of questionnaire the second time. The two questionnaire responses for the 15 respondents were used for a test-rest reliability estimate the results of the estimate are presented in Table 1.

\subsection{Data collection}

\subsubsection{Procedure for data collection}

A total of 54 questionnaires were administered in each of the six randomly selected wards. This gave an overall sampling size of 324. Using main streets/roads in each ward a systematic random approach was adopted in administering the questionnaires to the respondents.

Thus, for over fifth house in the main street/road a questionnaire was administered. However, a total of 306 questionnaires were returned properly filled. Eighteen questionnaires were not returned, improperly filled, or uncompleted. Table 2 indicates the distribution of the questionnaires by the core area of the municipality. 
Table 1. Test-retest reliability estimates of variables on opinion, beliefs and attitude of the Efiks, Quas and Efuts of Calabar Municipality towards the practice of female circumcision

\begin{tabular}{|c|c|c|c|c|c|}
\hline Independent variables & No. of items & Administration & $\overline{\mathbf{x}}$ & $S D$ & $\mathbf{r x}$ \\
\hline \multirow{2}{*}{$\begin{array}{l}\text { Opinion of the Efiks, Quas and } \\
\text { Efuts }\end{array}$} & \multirow{2}{*}{5} & $1^{\text {st }}$ & 13.4 & 2.63 & \multirow{2}{*}{0.67} \\
\hline & & $2^{\text {nd }}$ & 12.6 & 2.81 & \\
\hline \multirow{2}{*}{$\begin{array}{l}\text { Beliefs of the Efiks, Quas and } \\
\text { Efuts }\end{array}$} & \multirow{2}{*}{5} & $1^{\mathrm{st}}$ & 12.93 & 2.48 & \multirow{2}{*}{0.77} \\
\hline & & $2^{\text {nd }}$ & 12.86 & 2.65 & \\
\hline \multirow{2}{*}{$\begin{array}{l}\text { Attitude of the Efiks, Quas and } \\
\text { Efuts }\end{array}$} & \multirow{2}{*}{5} & $1^{\text {st }}$ & 12.49 & 2.84 & \multirow{2}{*}{0.65} \\
\hline & & $2^{\text {nd }}$ & 12.52 & 2.96 & \\
\hline
\end{tabular}

Table 2. Distribution of questionnaires by core areas of Calabar municipality

\begin{tabular}{llllll}
\hline Area & $\begin{array}{l}\text { Questionnaires } \\
\text { administered }\end{array}$ & $\begin{array}{l}\text { Returned } \\
\text { questionnaires }\end{array}$ & $\begin{array}{l}\text { Questionnaire } \\
\text { not returned }\end{array}$ \\
\hline Efik & 54 & 108 & $\begin{array}{l}107(53) \\
(54)\end{array}$ & 0 & 1 \\
Efut & 54 & 108 & $\begin{array}{l}102(51) \\
(54)\end{array}$ & 3 & 3 \\
Qua & 54 & 108 & $\begin{array}{l}97(52) \\
(54)\end{array}$ & 4 & 7 \\
\hline
\end{tabular}

Note. Properly filled questionnaires per ward

Thus, for the two wards in Efik area 53 and 54 questionnaires were returned and accepted; for Efut there were 51 and 51 and for Qua 52 and 54 returned and accepted questionnaires.

Before administering the questionnaires the chiefs in the selected wards were informed and asked for their support and cooperation with the researcher and her field assistants. They helped to inform the people of the need to cooperate with the researcher and her assistants in filling the questionnaires. Through such support and cooperation from the chiefs, it was possible for the people to gather in primary schools in their respective wards for group discussions with the researcher.

\subsubsection{Procedure for data analysis}

The data collected was therefore subjected to coding, editing and then analysis. Simple percentages and tables were used to display the research data.

\subsubsection{Data presentation and analysis}

The main focus of this section is the presentation and analysis of data. This is done under the following sub-heading.

- Socio-demographic data

- Research question by research question presentation of data

- Hypothesis testing

\subsubsection{Socio-demographic data}

The socio-demographic data of the respondents is presented in Table 3.

\subsubsection{Research question by research question on presenta- tion of results}

Research question 1 What is the opinion of the Efiks, Quas and Efuts of Calabar Municipality towards female circumcision? This research question is answered using frequencies and percentages as presented in Table 4 .

Research question 2 What are the beliefs of the Efiks, Quas and Efuts of Calabar Municipality towards female circumcision? This research question is answered using frequencies and percentages as presented in Table 5 .

Research question 3 What is the attitude of the Efiks, Quas and Efuts of Calabar Municipality towards female circumcision? This research question is answered using frequencies and percentages as presented in Table 6 .

\subsection{Data analysis}

\section{Hypothesis}

There is no significant relationship between the beliefs and attitude of Efiks, Quas and Efuts of Calabar Municipality towards the practice of female circumcision. This hypothesis is tested using Pearson product moment correlation analysis as presented in Table 7.

\section{RESUlts}

The result of findings revealed that a majority of Efiks, Quas and Efuts of Calabar Municipality perceive female circumcision as a bad practice. This result is in line with Mbiti, ${ }^{[7]}$ who considers female circumcision as a custom and that where it is practiced, everybody must bow to or face the penalty for defiance which was total ostracism. That even though, most of the people view it as a bad practice, they are left with no choice than to accept the practice because they are so rooted to their beliefs and culture.

In view of the health hazards posed to women and for the fact that many have come to see female circumcision as a form of violence against women ${ }^{[18]}$ and denial of sexual expressions, every measure and strategy should be adopted towards eradication of female circumcision. Such strategy 
should include the sensitization and education of opinion leaders, parents, youths, traditional birth attendants, circumcisers and outside the municipality on safe motherhood, child survival and dangers of female circumcision using outreach programmes. Preachers should be educated to debunk the myths surrounding female circumcision. Posters should be developed and made to sensitize the public including parent as well as the use of alternative media like folktales, drama and songs.

Table 3. Socio-demographic data of respondents

\begin{tabular}{|c|c|c|c|}
\hline Variable & Categories & Frequency & Percentage (\%) \\
\hline \multirow{4}{*}{ Age } & Below 21 & 52 & 17.0 \\
\hline & 21-30 years & 133 & 43.5 \\
\hline & $31-40$ years & 80 & 26.1 \\
\hline & 41-above & 41 & 13.4 \\
\hline \multirow{2}{*}{ Sex } & Male & - & - \\
\hline & Female & 306 & 100.0 \\
\hline \multirow{4}{*}{ Marital status } & Single & 114 & 37.3 \\
\hline & Married & 124 & 40.5 \\
\hline & Separated & 48 & 15.7 \\
\hline & Divorced & 20 & 6.5 \\
\hline \multirow{6}{*}{ Ethic group } & Efik & 90 & 29.4 \\
\hline & Efut & 54 & 17.6 \\
\hline & Quas & 60 & 19.6 \\
\hline & Yoruba & 7 & 2.3 \\
\hline & Igbo & 18 & 5.9 \\
\hline & Others & 77 & 25.2 \\
\hline \multirow{4}{*}{$\begin{array}{l}\text { Religion } \\
\text { affiliation }\end{array}$} & Christianity & 276 & 90.2 \\
\hline & Islam & 15 & 4.9 \\
\hline & African Traditional & 15 & 4.9 \\
\hline & Others & 0 & 0 \\
\hline \multirow{6}{*}{$\begin{array}{l}\text { Educational } \\
\text { qualification }\end{array}$} & No school at all & 57 & 18.6 \\
\hline & Primary six & 42 & 13.7 \\
\hline & WASC & 67 & 21.9 \\
\hline & OND/HND & 64 & 20.9 \\
\hline & B.Sc/M.Sc/Ph.D & 76 & 24.8 \\
\hline & Others & 0 & 0 \\
\hline \multirow{4}{*}{ Occupation } & Civil servant & 136 & 44.4 \\
\hline & Trading & 72 & 23.5 \\
\hline & Self employment & 55 & 18.0 \\
\hline & Unemployed & 43 & 14.1 \\
\hline \multirow{6}{*}{$\begin{array}{l}\text { Monthly } \\
\text { income }\end{array}$} & Below N2,500 & 33 & 10.8 \\
\hline & N2,501-N3,500 & 42 & 13.7 \\
\hline & N3,501-N4,500 & 57 & 18.6 \\
\hline & N4,501-N5,500 & 64 & 20.9 \\
\hline & N5,501-N6,500 & 44 & 14.4 \\
\hline & N6,501 \& above & 66 & 21.6 \\
\hline \multirow{6}{*}{$\begin{array}{l}\text { Number of } \\
\text { children }\end{array}$} & None & 46 & 15.0 \\
\hline & 1 & 53 & 17.3 \\
\hline & $2-3$ & 98 & 32.0 \\
\hline & $4-5$ & 72 & 23.5 \\
\hline & $6-8$ & 28 & 9.2 \\
\hline & $9 \&$ above & 09 & 3.0 \\
\hline Total & & 306 & 100.0 \\
\hline
\end{tabular}

The result is also in line with Bella, ${ }^{[1]}$ who pointed out that there is a serious controversy surrounding the continued practice of female circumcision even at the close of the $20^{\text {th }}$ century. This implies that, Information should also be disseminated using mass media and local languages. Workshops should be conducted during holidays for the youth (boys and girls) sensitizing them on the dangers of female circumcision. The circumcisers should be counseled and encouraged not to engage in the practice anymore and to diversity their source of income.

Table 4. Opinion of Efiks, Quas and Efuts of Calabar Municipality towards female circumcision

\begin{tabular}{lll}
\hline & Yes & No \\
\hline Do you support the practice of female & 64 & 242 \\
circumcision? & $(20.9)$ & $(79.1)$ \\
Will you encourage your younger sisters to & 59 & 247 \\
be circumcised? & $(19.3)$ & $(80.7)$ \\
Is a bad practice that should be stopped? & 244 & 62 \\
There is nothing wrong with the practice of & $(79.7)$ & $(20.3)$ \\
circumcision? & $(21.6)$ & 240 \\
Is the best way of protecting girls against & 56 & $(78.4)$ \\
men? & $(18.3)$ & $(81.7)$ \\
\hline
\end{tabular}

Note. Numbers in parentheses are percentages

Table 5. Beliefs of Efiks, Quas and Efuts of Calabar Municipality towards female circumcision

\begin{tabular}{lll}
\hline & Agree & Disagree \\
\hline Helps to reduce urge for sex among young & 204 & 100 \\
girls. & $(67.3)$ & $(32.7)$ \\
Only way word girls refuse to be circumcised. & 94 & 212 \\
& $(30.7)$ & $(69.3)$ \\
It is a taboo to get married without being & 73 & 233 \\
circumcised. & $(23.9)$ & $(76.1)$ \\
Only girls who have undergone circumcision & 77 & 229 \\
always make the best of house wife. & $(25.2)$ & $(74.8)$ \\
It has nothing to do with sexual activity in any & 124 & 182 \\
way. & $(40.5)$ & $(59.5)$ \\
\hline
\end{tabular}

Note. Numbers in parentheses are percentages

Table 6. Attitude of the Efiks, Quas and Efuts of Calabar Municipality towards female circumcision

\begin{tabular}{lll}
\hline & Agree & Disagree \\
\hline Is not a good cultural practice? & 164 & 142 \\
& $\mathbf{( 5 0 . 3 )}$ & $(49.7)$ \\
Young girls should reject the practice. & 184 & 122 \\
& $(60.1)$ & $(39.9)$ \\
Is a sort of punishment to the girl child? & 152 & 154 \\
Is a good way of protecting the girl child & $(49.7)$ & $(50.3)$ \\
from unwanted pregnancy? & 97 & 209 \\
Is the culture of your people and should not & 104 & $(68.3)$ \\
be stopped? & $(34)$ & 202 \\
\hline
\end{tabular}

Note. Numbers in parentheses are percentages

Legislation should be enacted and enforced by the Federal Government thus protecting girls from all forms of violence 
including genital mutilation. ${ }^{[11]}$ Although female circumcision cannot and must not be separated from other women's issues or social justice it deserves attention in its own right. ${ }^{[2]}$ It is therefore recommended that funding level for female circumcision programme must be similar to those for such high profile programmer, as children's health, women economic development and family planning.

Table 7. Pearson product moment correlation analysis of the relationship between beliefs and attitude of Efiks, Quas and Efuts towards the practice of female circumcision

\begin{tabular}{lllll}
\hline Variables & $\begin{array}{l}\sum \mathbf{x} \\
\sum \mathbf{y}\end{array}$ & $\begin{array}{l}\sum \mathbf{x}^{2} \\
\sum \mathbf{y}^{2}\end{array}$ & $\sum \mathbf{x y}$ & $\mathbf{R}$ \\
\hline $\begin{array}{l}\text { Beliefs on female } \\
\text { circumcision }\end{array}$ & 5,241 & 10,518 & & \\
$\begin{array}{l}\text { Attitude towards } \\
\text { female circumcision }\end{array}$ & 4,816 & 8,641 & & \\
\hline
\end{tabular}

Note. Significant at .05; critical $r=.113$; $\mathrm{df}=304$

The result of findings also revealed that the Efiks, Quas and Efuts of Calabar Municipality believe that female circumcision helps to reduce urge for sex among young girls, and that not only girls who have undergone circumcision make the best of house wife. Therefore this is a mere misconception. An institution similar to Nigerian Drug Enforcement Agency, Road Safety Commission, etc. with powers to coordinate the efforts and activities of health authorities and social organizations on matters concerning child abuse and female circumcision should be established. Such institution should also be given the power to enforce legislations on the child abuse and female circumcision.

Carmel $^{[12]}$ observed that Africans also maintain the belief that by removing parts of the sexual organs and thus preventing her attaining pleasure she will not be tempted in extramarital affair? The result of findings again showed that respondents exhibited a negative attitude towards the practice of female circumcision. There was also a significant relationship between the beliefs and attitude of Efiks, Quas and Efuts of Calabar Municipality towards the practice of female circumcision. Many groups have been campaigning against female circumcision such groups include women in Nigeria, National Council of Women Societies and many others. These groups and associations should be encouraged and as well as funded by individuals, private and public organizations as well as government to sensitize and educate persons on the hazard of female circumcision.

\section{Discussion}

The main focus of this study was to help in the reduction of excision in Calabar particularly and Africa in general. To suc- cessfully achieve this aim, the following research questions and hypothesis were formulated to guide the study:

(1) What is the opinion of the Efiks, Quas and Efuts of Calabar Municipality towards female circumcision?

(2) What are the beliefs of the Efiks, Quas and Efuts of Calabar Municipality towards female circumcision?

(3) What is the attitude of the Efiks, Quas and Efuts of Calabar Municipality towards female circumcision?

That hypothesis states that, there is no significant relationship between the beliefs and attitude of Efiks, Quas and Efuts of Calabar Municipality towards the practice of female circumcision. Literature was reviewed based on the research variables. The questionnaire which was administered on three hundred and six (306) respondents who served as the sample size for the study was the instrument used for data collection.

The data obtained from the responses was analyzed using descriptive statistics of frequencies and percentages, and Pearson product moment correlation analysis and the following results were obtained.

(1) About $80 \%$ of the Efiks, Quas and Efuts of Calabar Municipality perceive female circumcision as a bad practice.

(2) About 70\% of the Efiks, Quas and Efuts of Calabar Municipality believe that female circumcision helps to reduce urge for sex among young girls and that not only girls who have undergone circumcision make the best of house wives.

(3) About $60 \%$ of the respondents showed a negative attitude to the practice of female circumcision.

(4) There is a significant relationship between the beliefs and attitude of Efiks, Quas and Efuts of Calabar Municipality towards the practice of female circumcision.

\section{Conclusion}

Based on the findings of the study, it was concluded that female circumcision was considered as a bad practice, it was also considered to assist young girls to reduce their urge for sex and, the Efiks, Quas and Efuts of Calabar Municipality showed a negative attitude towards the practice of female circumcision.

It was again concluded that there was a significant relationship between the believed and attitude of Efiks, Quas and Efuts of Calabar Municipality toward the practice of female circumcision. 


\section{REFERENCES}

[1] Bella H. Female Circumcision. African Health. 2007; 2(6): 31-32.

[2] Toubia N. Female Circumcision Mutilation Rainbow. 2010.

[3] Oyira EJ. Attitude of women toward the practice of female circumcision among Agwagune in Biase Local Government Area Cross River State Nigeria unpublished. 2010.

[4] The Encyclopaedia. Americana. 1991; 6: 735.

[5] Talbot PA. Southern Nigeria: Ethnology: Frank Cass. 2008.

[6] Available from: http://www.african.women.org/FGM

[7] Mbiti JS. African religion of philosophy. Marison and Gibb Limited. 2008.

[8] Klein HL. Prisoners of Ritual: An Odyssey into Female Circumcision in Africa. New York: Harrington Park Press; 2004.

[9] Ogunmodede E. End this Mutilation People. 2010; 6(1): 30-31.
[10] Koso-Thomas O. The Circumcision of Women: A Strategy for eradication. London: Zed Books; 2010. PMid: 21156060.

[11] Sequiera JH. Female Circumcision and Infibulations. The Lancet. 2013; 11: 1054-1055.

[12] Carmel UN. A Research into the Effects of Circumcision on Females in Bette Clan of Obudu Local Government Area of Cross River State. Diploma Thesis. 2012.

[13] Kenyatta J. Facing Mount Kenya. New York: Vintage Press; 2010.

[14] Epelboin S, Epelboin A. Special Report Female Circumcision People. $2006 ; 6$.

[15] Thomas L. The Clitoris: St. Louis mo Warren Green. 2013.

[16] Hayes BO. Female Genital Mutilation Fertility Control. Women's Role and Patrilineage in Modern Sudan: A Functional Analysis American Ethnotogist. 2000; 2(4): 617-633.

[17] Projected population. 2006.

[18] Fourth world conference on women. Beijing; 1995. 